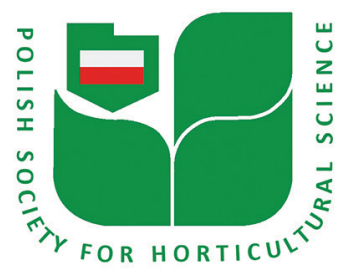

Folia Hort. 32(2) (2020): 265-278

\title{
Effect of no-tillage and tillage systems on melon (Cucumis melo L.) yield, nutrient uptake and microbial community structures in greenhouse soils
}

\author{
Jian Zhang ${ }^{1,2, *}$, Jiajia Wang ${ }^{3}$, Pengcheng Wang ${ }^{1,2}$, Tingting Guo ${ }^{1,4}$ \\ ${ }^{1}$ Institute of Horticulture, Anhui Academy of Agricultural Sciences, Hefei 230031, Anhui Province, China \\ ${ }^{2}$ Key Laboratory of Genetic Improvement and Ecophysiology of Horticultural Crops, Hefei 230031, Anhui Province, China \\ ${ }^{3}$ Soil and Fertilizer Research Institute, Anhui Academy of Agricultural Sciences, Hefei 230031, Anhui Province, China \\ ${ }^{4}$ School of Life Sciences, Anhui Agricultural University, Hefei 230036, Anhui Province, China
}

\begin{abstract}
No-tillage (UT) and tillage (TL) influence melon (Cucumis melo L.) production. However, the mechanism of improving the soil quality under UT in melon production is still unavailable. In this study, we attempted to explore the effects of UT and TL treatments on soil fertility and the microbial abundance and diversity in planting melon under greenhouse condition. Soil properties were determined and the bacterial v4-v5 $16 \mathrm{~S}$ rRNA and the fungal internal transcribed spacer gene were pyrosequenced by extracting greenhouse soil DNA. Results showed that the two treatments had different effects on nutrient uptake in melon plants under facility conditions. Additional nitrogen $(\mathrm{N})$ was absorbed in the leaves and fruit in UT treatment. However, the N content in the UT treatment was kept as similar to that of the TL treatment. The phosphorus (P) contents in melon plant leaves and fruits in the UT treatment were higher than those in the TL treatment. High potassium $(\mathrm{K})$ contents were observed in fruits and melon stem under the UT and TL treatments, respectively. Soil $\mathrm{pH}$, organic matter and the available $\mathrm{N}$ influenced the bacterial and fungal distributions. The total $\mathrm{N}$, total $\mathrm{P}$ and total $\mathrm{K}$ in melon plants were correlated with the bacterial and fungal groups in facility soils. The UT treatment had a substantial effect on the microbial diversity in soils planted with melon. Our study provided insights into the response of soil fertility and microbial structures to UT and TL treatments under greenhouse soils, which may aid in managing greenhouse soil quality.
\end{abstract}

Keywords: bacterial structure, facility production, melon crop, soil quality, tillage operations

\section{INTRODUCTION}

The greenhouse industry has become one of the most important components for the development of agriculture. Nowadays, the vegetable greenhouse industry has been greatly promoting the world's economy. The greenhouse industry is developing rapidly in China, which accounts for more than all global greenhouse cultivation areas (Chang et al., 2013; Wang et al., 2017a). After the increase in this production style, the supply of fresh and off-season vegetables on the market has improved (Chang et al., 2011). Greenhouse production should be developed consistently in future agricultural systems (Muller et al., 2017). Initially, sole cropping is used in the greenhouse production, but with increased market demand, intercropping or two times of repeated planting per year has been done in the greenhouse (Firouzi et al., 2017; Wang et al., 2014). As a result, the improvement of the cultivation environment conditions in the greenhouse has become the priority in growing crops, especially in protecting soil quality and fertility (Yeboah et al., 2018). Therefore, maintaining production and improving or 
balancing soil quality have become important in greenhouse production.

Melon (Cucumis melo L.) plays an important role in the horticulture industry, and it is considered as one of the 10 most popular cultivated fruits in the world. To date, melon is an economically important fruit crop, and its production has become extremely popular in China (Cao et al., 2019; Zhang et al., 2016b), especially under greenhouse cultivation. Considering the market demands and economic incentives, melon cultivation has rapidly expanded (Li et al., 2019; Zhang et al., 2016a). However, intensive melon cultivation decreases the chemical and biological attributes of soil (Guo et al., 2010) and causes significant changes in its physical properties (Hu et al., 2017). At present, reduced tillage (TL) treatment has gained popularity in today's agriculture in China and Europe (Dhaene et al., 2008). Melon production systems in China often rely on no-tillage (UT) and plastic houses (Yan et al., 2019). Nowadays, farmers show preference to UT treatment in growing melon to reduce the costs of production and labour. Nevertheless, concerns about the improvement of soil properties and fertilities for the next production season are still present.

Reduced TL systems can increase long-term soil productivity and health (Tillman et al., 2015). However, depending on the melon variety, growers can reduce yields compared with TL to avoid soil compaction and low fertility. Reduced TL systems can produce similar or higher yields than conventional TL systems in vegetablecrops (Haramoto and Brainard, 2012; Tillman et al., 2015). However, UT is one form of conservation TL that has been widely adopted in agricultural production to improve soil sustainability (O'Rourke and Petersen, 2016). The UT treatment is widely applied in vegetable production, but striking a balance between retention of soil nutrients and quality, and increased production is still a contentious issue. Microbes are extremely abundant in soils and play important roles in soil productivity and biogeochemistry (Kumar et al., 2019). Microbial groups, such as beneficial bacteria and fungi, maintain soil functionalities and promote plant growth (Kandlikar et al., 2019; Touceda-González et al., 2015). Microbial diversity increases soil quality and fertility. Thus, increasing microbial diversity can improve greenhouse practices to maintain soil health and quality (Karlen et al., 2019; Xue et al., 2020). It is useful to analyse the microbial community structures and microbial abundance and diversity in UT and TL soils in the greenhouse. It can be considered as one of the important indicators for greenhouse soil fertility.

Despite the availability of various soils management practices (e.g. soil texture, nutrient and irrigation), the mechanism of improving soil quality under UT practice for facility production is still unavailable, causing difficulties and confusion in melon production. Given that UT and TL influence agriculture production and the soil environment, we attempted to explore the effects of these treatments on microbial abundance and diversity under facility condition. In this study, the pyrosequencing of the V4-V5 16S rRNA and fungi internal transcribed spacer (ITS) gene region were used to analyse microbial community structures in UT and TL soils. The melon yield and the correlation of soil microbial communities under UT treatment were also investigated under facility conditions.

\section{MATERIALS AND METHODS}

\section{Plant materials}

Grafted melon seedlings were used in this study. The scion was a cultivated melon variety, 'Cuimi'. This cultivar was suitable for greenhouse cultivation, and it could be available in the market in the near future. The rootstock was a pumpkin (Cucurbita moschata) cultivar (Wanzhen 2) and exhibited good graft compatibility and fruit quality. Now, it turned out to be one of the most popular rootstocks available for watermelon and melon grafting in Anhui Province, China.

\section{Experimental site and soil sampling}

The greenhouse experiment was accomplished in a planting base in Hexin County $\left(118.35^{\circ} \mathrm{E}\right.$ and $\left.31.74^{\circ} \mathrm{N}\right)$, Anhui Province, China. Soil samples were collected thrice from January 1, 2018, to August 31, 2019. A total of 18 rhizosphere soil samples were collected from 10 points by using a sterile blade at a depth of $0-15 \mathrm{~cm}$ and composited together. Each sample was then divided into two portions. One portion was stored at $4{ }^{\circ} \mathrm{C}$ for biogeochemical analysis and the other one at $-80^{\circ} \mathrm{C}$ for DNA analysis.

\section{Protected field trial}

A protected field experiment with two operation practices (i.e. UT and TL treatments) was conducted in Hexin County. Soil pH ranged between 7.1 and 7.3, and the organic matter (OM) ranged from 20 to $22 \mathrm{~g} \cdot \mathrm{kg}^{-1}$ in two treatments. The complete basic soil properties are listed in Table 1. The soil was tilled with a depth of $20-35 \mathrm{~cm}$ in TL. Ridging ways and planting density were arranged the same way as UT. Grafted melon seedlings were transplanted at the beginning of January 2019 under greenhouse soils. Normal and regular management was followed to maintain melon seedling growth in UT and TL treatments. Before the fruit setting time, $20 \mathrm{~kg} \cdot 667 \mathrm{~m}^{-2}$ fertiliser (N:P:K ratio of 3:1:3) was added to plant soils. The experiment was terminated at the end of July 2019. The melon matured within 80 days from planting. The average yield from $667 \mathrm{~m}^{2}$ was recorded immediately after harvest. Five fruits from each replicate were randomly selected to assess fruit weight (kg) and nutrient elements. Ten plants were used with three replicates.

\section{Determination of soil properties}

Soil $\mathrm{pH}$ and $\mathrm{OM}$ content were detected following our previously reported methods (Zhang et al., 2019). The total N (TN) and alkaline $\mathrm{N}(\mathrm{AN})$ of the soil and the $\mathrm{N}$ content of the plant were determined following a 
reported method (Bremner, 1960). The total P (TP) in the melon plant was determined using the combustion and the molybdenum blue colorimetric methods (Sjösten and Blomqvist, 1997). Available P (AP) was extracted and detected following the procedures of a reported method (Li et al., 2004). Soil available K (AK) and plant total $\mathrm{K}$ were measured using flame atomic absorption spectrophotometry following a previous method (Zhang et al., 2019).

\section{Soil DNA extraction}

Approximately, $0.5 \mathrm{~g}$ of fresh rhizosphere soil was used to extract soil DNA in triplicate from each soil site by using the MoBio Power Soil DNA Isolation Kits (MoBio Laboratories, Carlsbad, CA, USA) following the manufacturer's instructions. The purity of the soil DNA extracts was determined using the NanoDrop ${ }^{\mathrm{TM}}$ 2000 spectrophotometer (NanoDrop Technologies, Wilmington, DE, USA). The obtained DNA was stored at $-80^{\circ} \mathrm{C}$ for future analyses.

\section{Gene amplification for sequencing}

The amplification of 16S rRNA for sequencing was performed following a previously described method (Shen et al., 2013; Zhang et al., 2019). Briefly, the V4-V5 regions of the bacterial 16S rRNA genes were amplified using the primers F515 and R907. The primers ITS1 and ITS2 were used to amplify the ITS genes (Table 2). PCR was performed following a previous report (Zhang et al., 2019). The PCR products were purified, and sequencing was performed using the Illumina MiSeq platform from Biozeron Biotechnology Co., Ltd. (Shanghai, China).

\section{Sequence analysis}

The operational taxonomic units (OTUs) with identities of $97 \%$ were identified using the Mothur software (http://www.mothur.org). The sequence with the highest relative abundance in each OTU was chosen as the representative sequence. They were selected to search for similar sequences in the nucleotide nonredundant database from the National Center for Biotechnology
Information (NCBI) following a previously reported method (Sun et al., 2015).

\section{Statistical analysis}

All data were analyzed using a one-way analysis of variance and considered statistically significant and highly significant at $p<0.05\left(^{*}\right)$ and $p<0.01(* *)$, respectively, by using the SPSS software (version 17.0). To determine the functional groups of microbes in the soils, we performed the LEfSe analysis by using a previously reported method (Zhang et al., 2013). The canonical correspondence analysis (CCA) and the redundancy analysis (RDA) were also performed to analyse the effect of soil factors (e.g. pH, AN, AP and $\mathrm{AK}$ ) on the microbial communities (Zhou et al., 2018). All the sequence data of bacteria and fungi were deposited in the NCBI Sequence Read Archive database with the accession number of SRP241843.

\section{RESULTS}

\section{Nutrient uptake and yields in melon plants}

In this study, two operation practices (i.e. UT and TL) were used. Under the UT and the TL treatments, the N, $\mathrm{P}$ and $\mathrm{K}$ were absorbed similarly by the melon plant, but the total amounts of absorbed nutrients were different. The differences in nutrient contents in leaves were significant. The most absorbed element was N. The N, $\mathrm{P}$ and $\mathrm{K}$ contents in the UT treatment were 2.71, 0.51, and $1.04 \mathrm{~g} \cdot$ plant $^{-1}$ (Figure 1A), respectively. The N, $\mathrm{P}$ and $\mathrm{K}$ contents in the TL treatment were 1.94, 0.35 and $0.89 \mathrm{~g} \cdot$ plant $^{-1}$, respectively. The $\mathrm{N}$ content was the highest, followed by $\mathrm{K}$, and the $\mathrm{P}$ content was the lowest. The N content of the UT treatment was significantly higher than that of the TL treatment.

In the stem of the melon plant, the N, P and K contents in the UT treatment were $0.52,0.09$ and $0.65 \mathrm{~g} \cdot$ plant $^{-1}$ (Figure 1B), respectively. The $\mathrm{N}, \mathrm{P}$ and $\mathrm{K}$ contents in the TL treatment were $0.53,0.08$ and $0.97 \mathrm{~g} \cdot$ plant $^{-1}$, respectively. $\mathrm{K}$ was the most absorbed, followed by $\mathrm{N}$, and $\mathrm{P}$ was the least absorbed. The $\mathrm{K}$ content in the stems

Table 1. Basic properties of soils in two treatments

\begin{tabular}{|c|c|c|c|c|c|c|c|c|}
\hline \multirow[t]{2}{*}{ Treatment } & \multirow[t]{2}{*}{$\mathrm{pH}$} & $\mathrm{OM}$ & $\mathrm{TN}$ & $\mathrm{TP}$ & TK & $\mathrm{AN}$ & AP & $\mathrm{AK}$ \\
\hline & & \multicolumn{3}{|c|}{$\mathrm{g} \cdot \mathrm{kg}^{-1}$} & & \multicolumn{3}{|c|}{$\mathrm{mg} \cdot \mathrm{kg}^{-1}$} \\
\hline UT & $7.30 \pm 0.05$ & $20.70 \pm 0.08$ & $1.07 \pm 0.02$ & $1.91 \pm 0.04$ & $6.34 \pm 0.09$ & $155.23 \pm 3.21$ & $89.42 \pm 2.12$ & $686.05 \pm 3.14$ \\
\hline TI & $7.12 \pm 0.03$ & $22.01 \pm 0.11$ & $1.18 \pm 0.05$ & $1.69 \pm 0.07$ & $5.81 \pm 0.02$ & $163.51 \pm 1.51$ & $95.61 \pm 1.11$ & $767.00 \pm 1.89$ \\
\hline
\end{tabular}

$\mathrm{AK}$, available potassium; $\mathrm{AN}$, available nitrogen; $\mathrm{AP}$, available phosphorus; $\mathrm{OM}$, organic matter; TI, tillage; TK, total potassium; TN, total nitrogen; TP, total phosphorus; UT, no-tillage.

Table 2. Oligonucleotide primers for PCR

\begin{tabular}{llll}
\hline Microbes & Regions & Forward primer $\left(5^{\prime}-3^{\prime}\right)$ & Reverse primer $\left(5^{\prime}-3^{\prime}\right)$ \\
\hline Bacteria & V4-V5 & GTGCCAGCMGCCGCGG & CCGTCAATTCMTTTRAGTTT \\
Fungi & ITS1 & CTTGGTCATTTAGAGGAAGTAA & GCTGCGTTCTTCATCGATGC \\
\hline
\end{tabular}



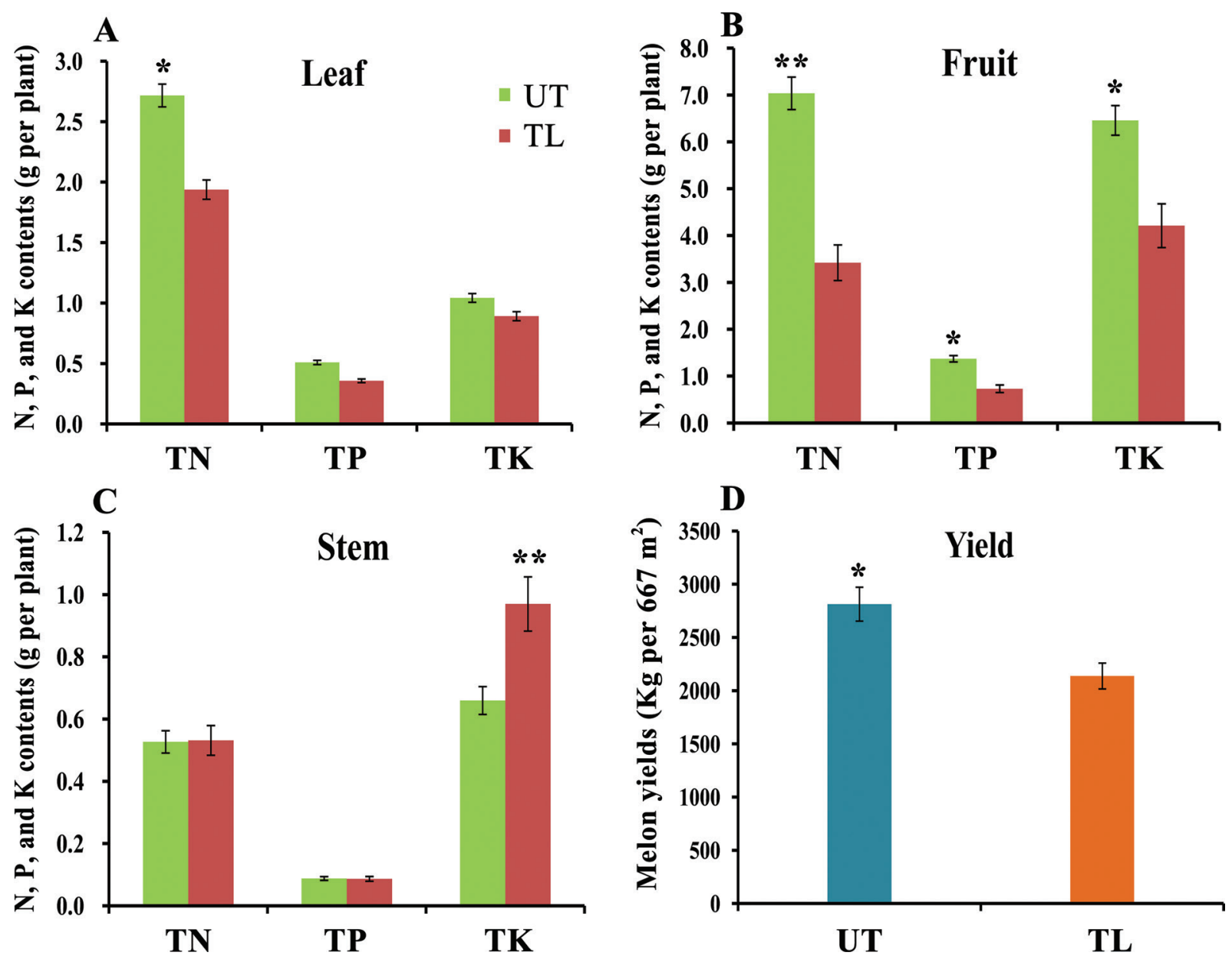

Figure 1. Nutrient uptake in melon plant's leaf, stem, and fruit and yield analysis. Differences were considered statistically significant and highly significant at $p<0.05\left(^{*}\right)$ and $p<0.01(* *)$, respectively. Abbreviations: TK, total potassium; TN, Total nitrogen; TP, total phosphorus. UT and TL present no-tillage and tillage treatments, respectively.

in the TL treatment was significantly higher than that in the UT treatment.

In melon fruit, the $\mathrm{N}, \mathrm{P}$ and $\mathrm{K}$ contents in the UT treatment were 7.04, 1.37 and $6.45 \mathrm{~g} \cdot$ plant $^{-1}$, respectively. The $\mathrm{N}, \mathrm{P}$ and $\mathrm{K}$ contents in the TL treatment were 3.42, 0.73 and $4.21 \mathrm{~g} \cdot$ plant $^{-1}$ (Figure 1C), respectively. The $\mathrm{N}, \mathrm{P}$ and $\mathrm{K}$ contents in the UT treatment were significantly higher than those in the TL treatment. The total contents of the three elements in the UT treatment $\left(20.41 \mathrm{~g} \cdot\right.$ plant $\left.^{-1}\right)$ were significantly higher than those in the TL treatment $\left(13.14 \mathrm{~g} \cdot\right.$ plant $\left.^{-1}\right)$. The melon yields in the UT and TL treatments were 2813.34 and $2138.32 \mathrm{~kg} \cdot 667 \mathrm{~m}^{-2}$, respectively (Figure 1D), indicating that the UT treatment increased melon yield.

\section{Analysis of the diversities of microbial communities}

The distribution of the clustered bar showed that the bacterial species (A) was significantly higher than the fungal species (B). The distribution characteristics of the microbial communities in UT and TL treatments were similar. The main bacterial phyla included Proteobacteria, Acidobacteria, Actinobacteria,
Gemmatimonadetes and Chloroflexi (Figure 2A), whereas that of fungi was Ascomycota (Figure 2B). The analysis of the bacterial distribution showed no significant difference in the distribution level of the bacterial species in the UT and the TL treatments even when the soil samples were measured at different periods (Figure 3). The thermogram of fungal distribution showed that UT and TL influenced the fungal community and showed differences (UT1 and TL1). The difference in species distribution between the two periods after planting was not significant (Figure 4). The bacterial OTUs were 1785, 1816, 1776, 1753, 1686 and 1767 in UT1, UT2, UT3, TL1, TL2 and TL3 soil samples (Figure 5A), respectively. A total of 689 OTUs were common in all samples, but the fungal OTUs were minimally observed. Rhodobiaceae, a bacterial genus, was the most significant community in cultivated TL soil. The functional communities in the UT treatment were higher than those of the TL treatment (Figure 5B).

\section{CCA and heatmap analyses of soil factors in microbial communities}

The CCA correlation showed a significant negative correlation between the $\mathrm{pH}$ value and Patescibacteria 

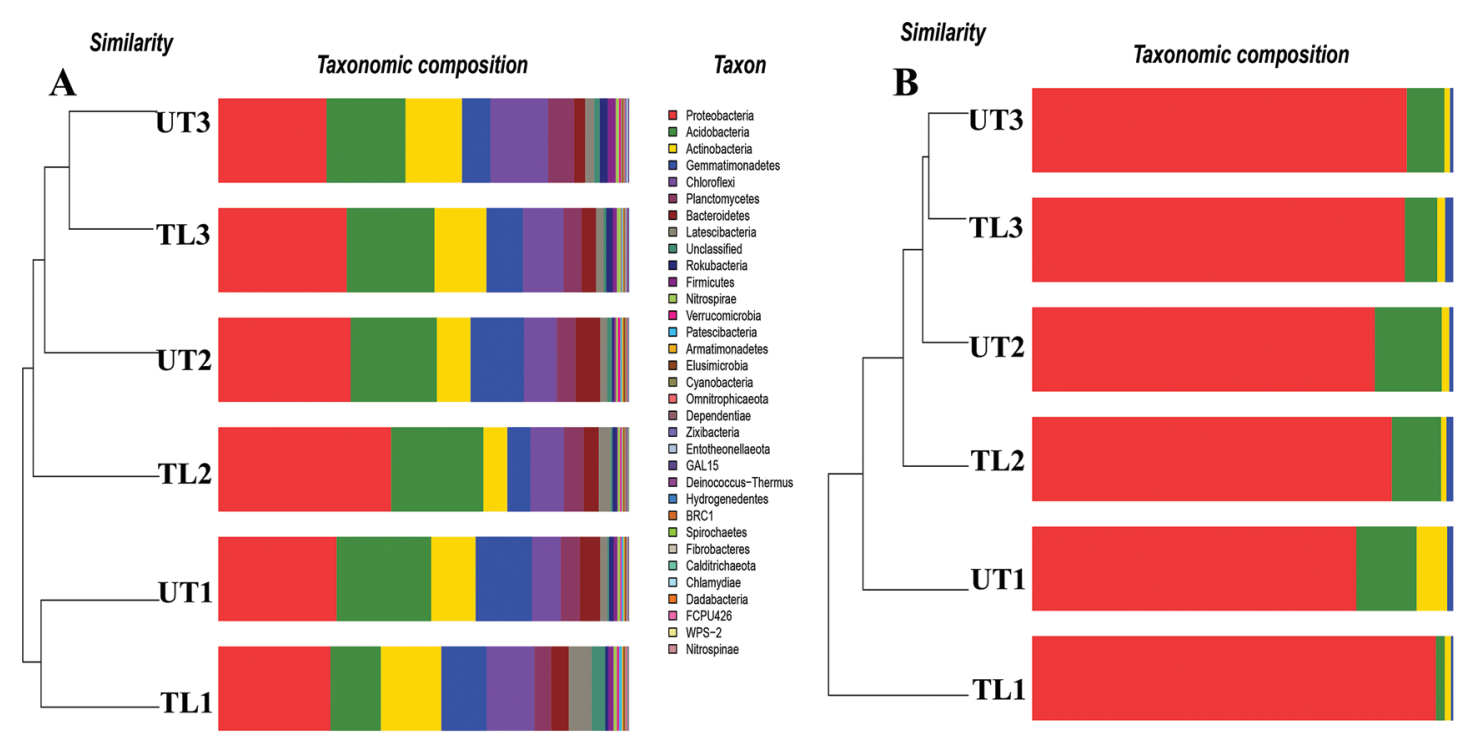

Figure 2. Microbial community bar plot with cluster tree. Relative abundances of bacterial (A) and fungal (B) phyla in soils under no-tillage and tillage treatments.

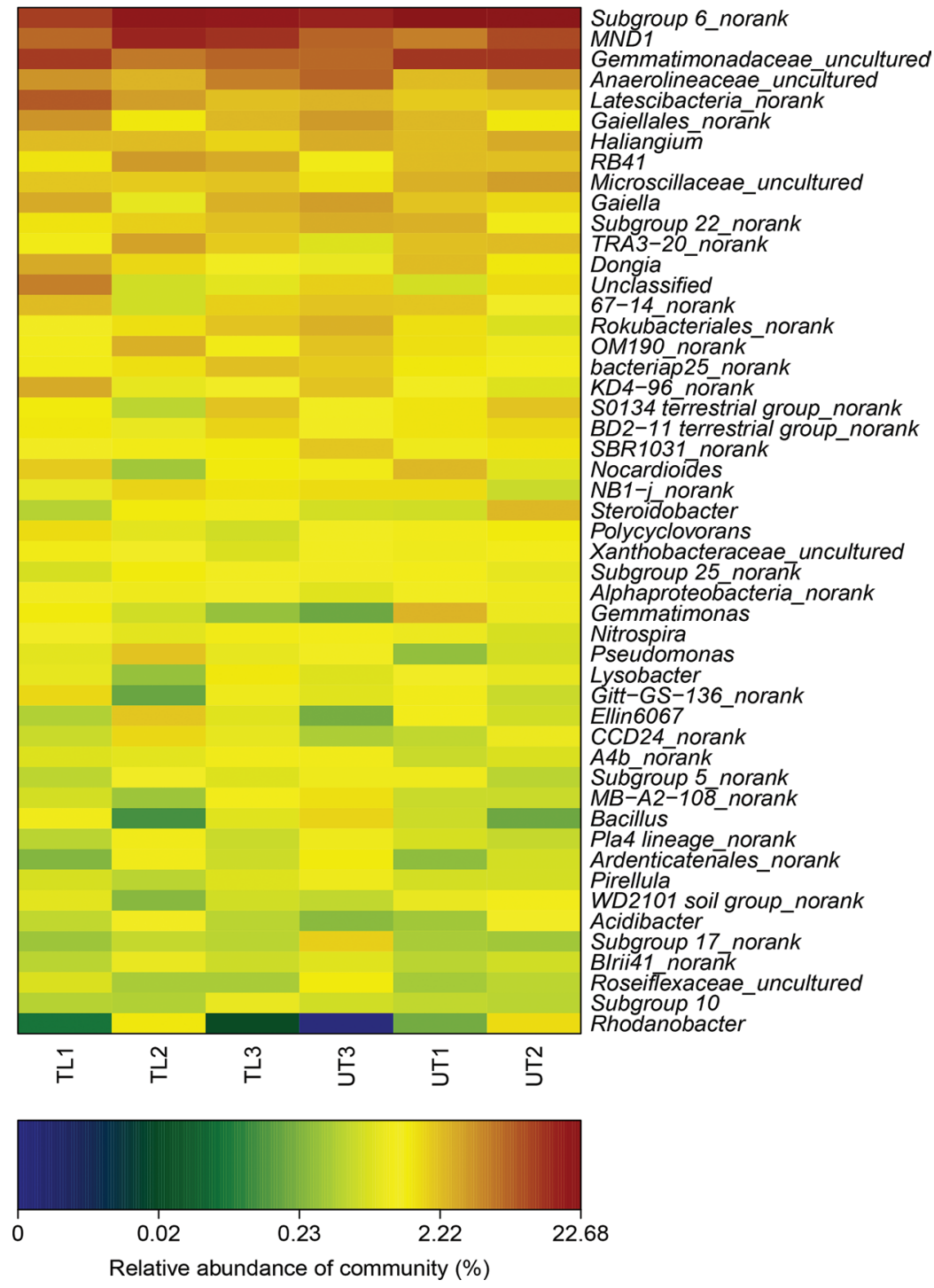

Figure 3. Bacterial community heatmap analysis at the genus level. 

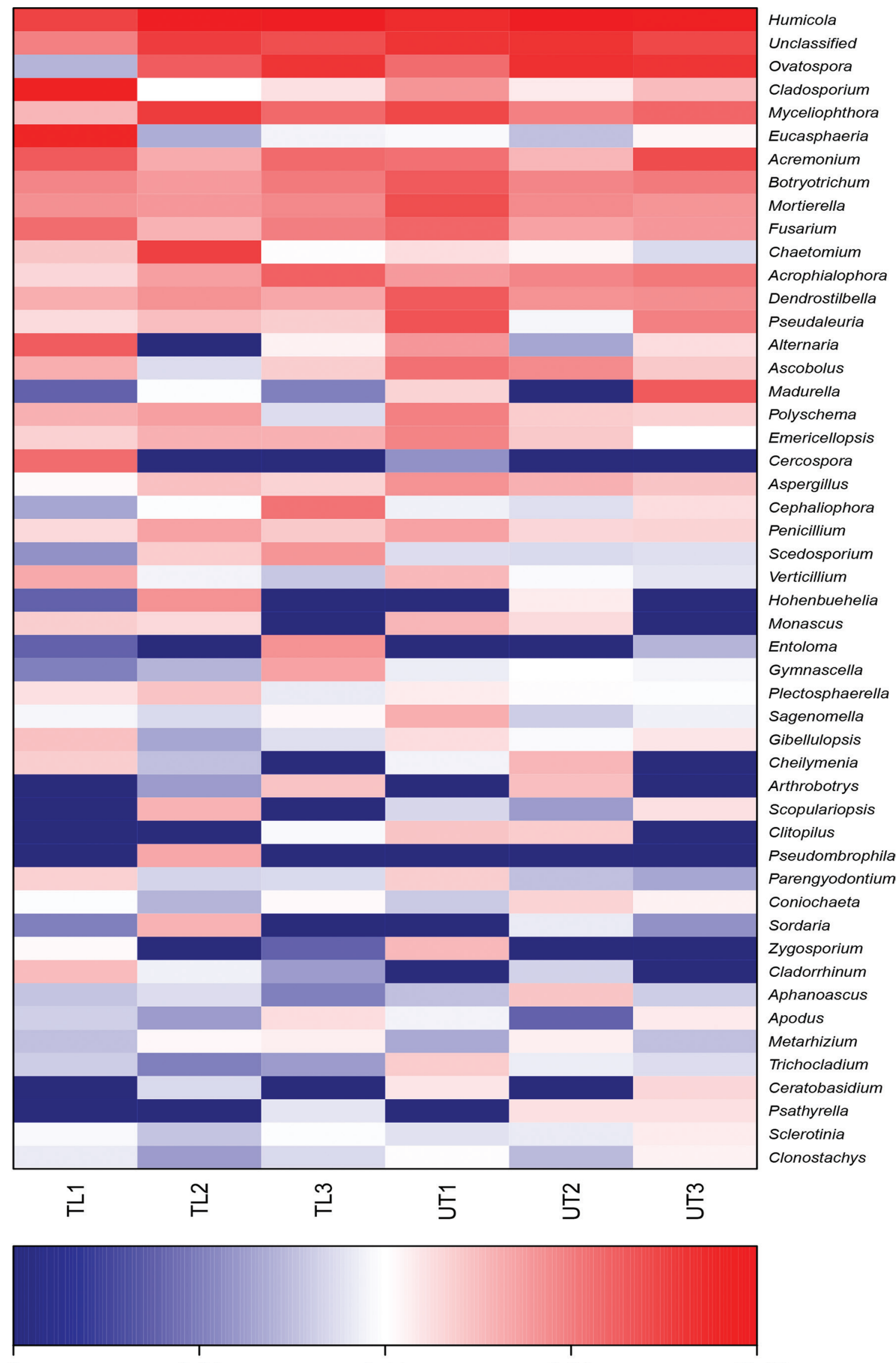

0

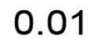

0.11

2.26

47.47

Relative abundance of community (\%)

Figure 4. Fungal community heatmap analysis at the genus level. 
and Armatimonadetes groups. Gemmatimonadetes, Bacteroidetes and Elusimicrobia were negatively correlated with $\mathrm{OM}$ and AN (Figure 6A). Verticillium was negatively correlated with $\mathrm{pH}, \mathrm{OM}$ and $\mathrm{AN}$ in the fungal community. Ascobolus was negatively correlated with OM, AN, AP and AK. Acrophialophora was

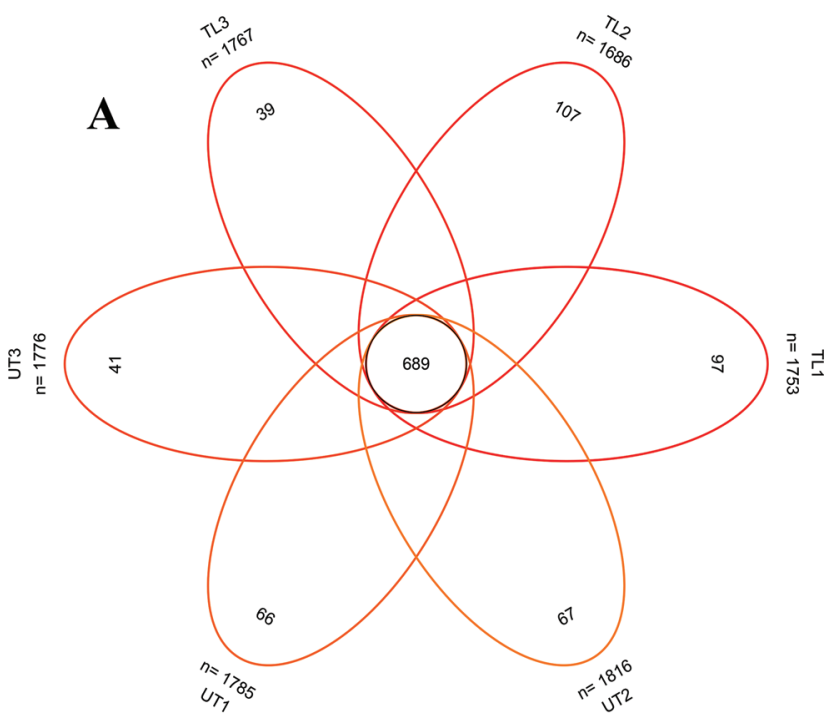

positively correlated with $\mathrm{pH}$ (Figure 6B). CCA showed that $\mathrm{pH}$ was the main factor affecting bacteria, followed by $\mathrm{OM}$ and $\mathrm{AN}$ content (Figure 7). CCA also showed that $\mathrm{AN}, \mathrm{OM}$ and $\mathrm{pH}$ were the main factors affecting fungal communities in the UT and the TL treatments (Figure 8).

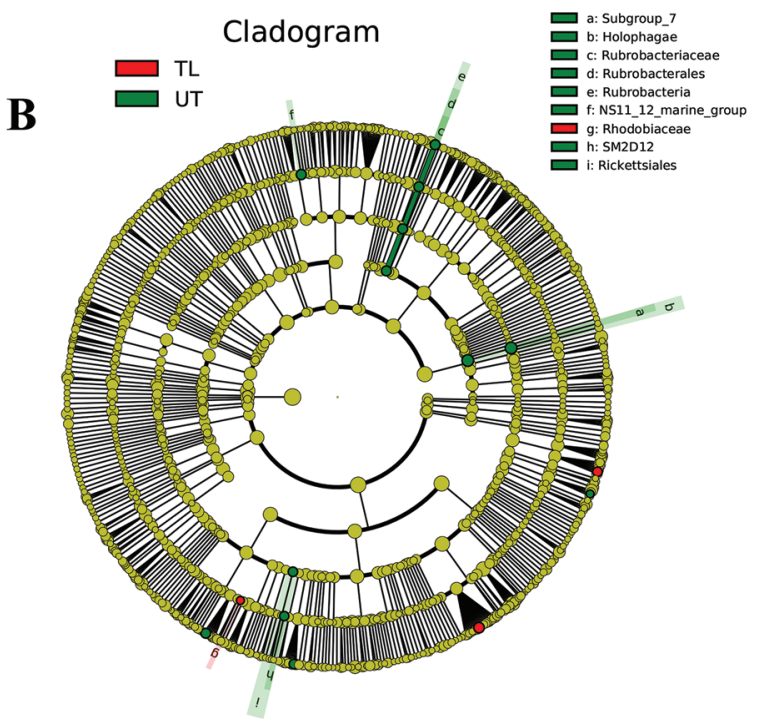

Figure 5. OTU Venn (A) and LEfSe (B) analyses of bacteria in no-tillage and tillage treatments.
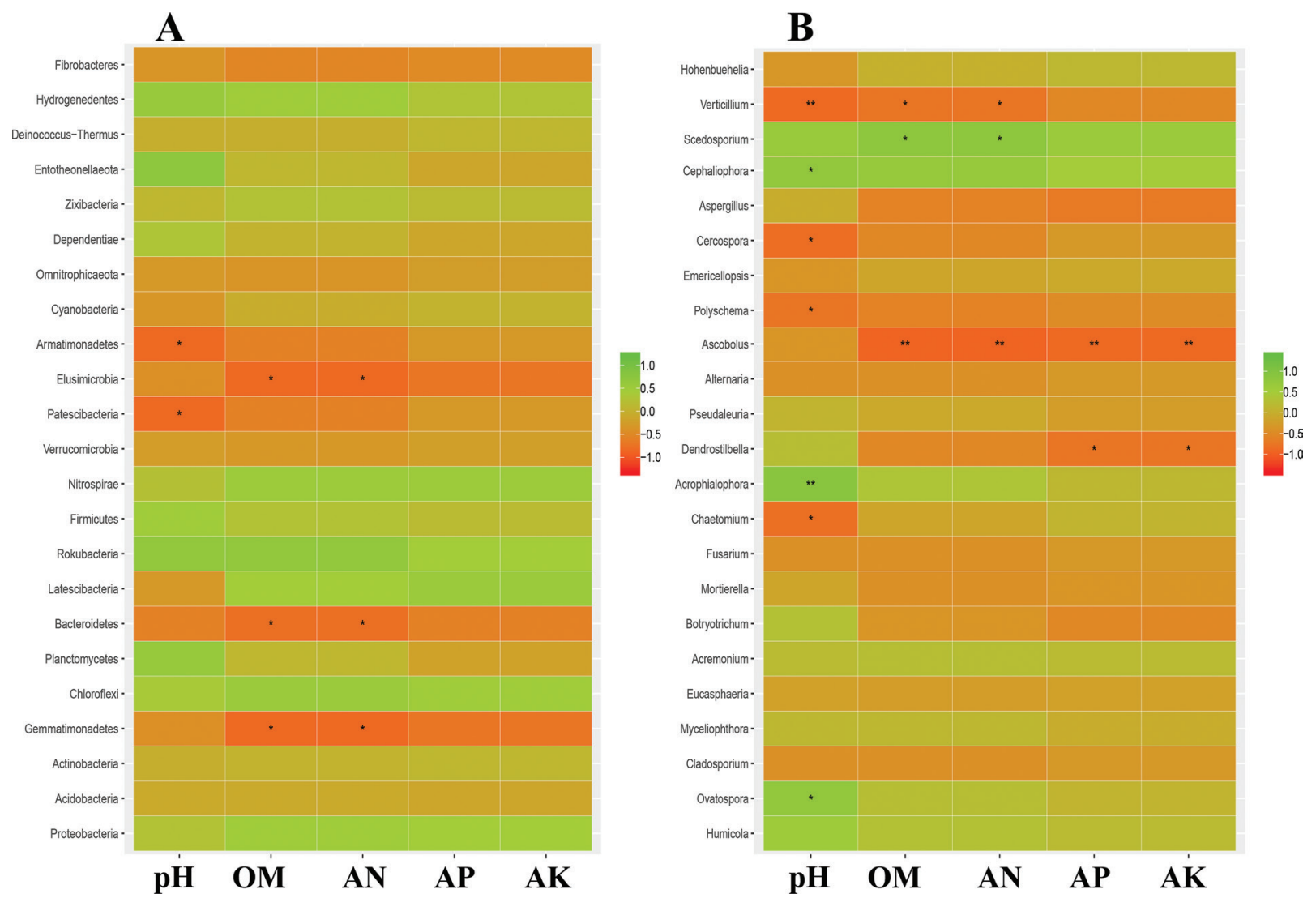

Figure 6. Redundancy analysis of bacterial (A) and fungal (B) communities in no-tillage and tillage soil samples; heatmap of correlations. * and ** means significant correlations at $p<0.05$, and $p \leq 0.01$, respectively. Abbreviations: $\mathrm{AK}$, available K; AN, alkaline nitrogen; AP, available P; OM, organic matter. 
CCA

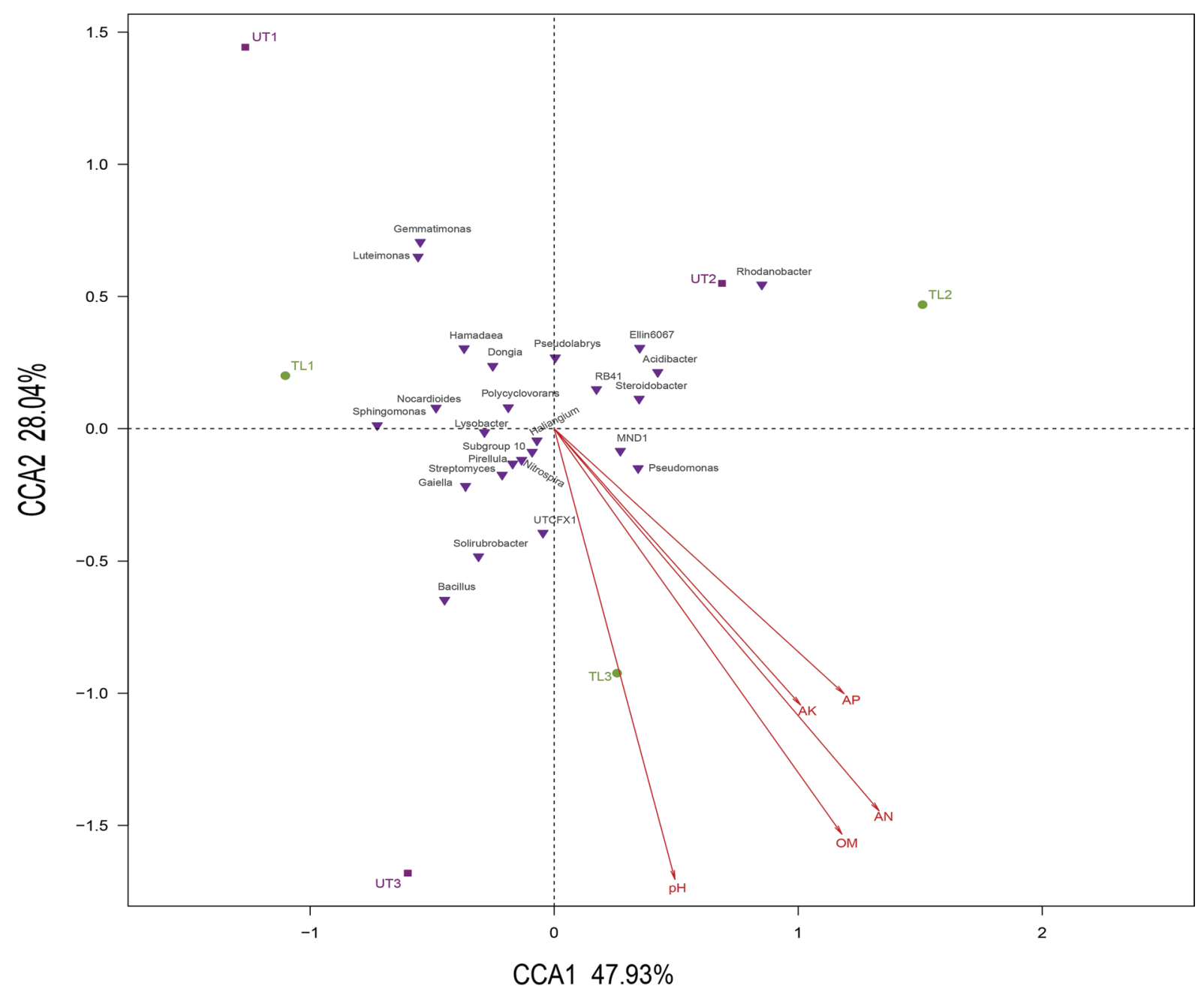

Figure 7. Biplot of species - environmental variables according to the CCA of bacterial taxa.

\section{Correlation of melon plant nutrients with soil microbial communities}

The correlation of the N, P and $\mathrm{K}$ contents absorbed by the leaves, stems and fruits of the melon plants with the soil microbial communities was further studied. The TN, TP, and TK contents of the leaves and fruits were significantly positively correlated with the bacterial genus Pirellula $(p<0.05)$. However, the TN and the TP in the stem were negatively correlated with Dongia, Gemmatimonas, Hamadaea and Nocardioides (Table 3). The bacterial phyla Patescibacteria and Armatimonadetes had a negative correlation with the TP in the stem. However, the bacterial phylum Planctomycetes was significantly positively correlated with the TP in the melon stem.

Concerning fungal genus communities, the $\mathrm{TN}, \mathrm{TP}$ and TK contents in melon leaves and fruits were negatively correlated with Chaetomium and positively correlated with Dendrostilbella. In the stem, TN was positively correlated with fungal genera Acrophialophora, Cephaliophora and Scedosporium. Fungal communities, such as Polyschema, Cercospora,
Verticillium, Fusarium, Dendrostilbella, and Ascobolus, were negatively correlated with the TN, TP, and TK contents (Table 3). Although the nutrients in the melon plant were correlated with bacterial or fungal genera in facility soils, no direct evidence in this work proved that those microbial groups increased or affected the absorption of elements in the melon plant.

\section{DISCUSSION}

\section{Nutrient uptake and yields in melon plants}

The TL and the UT treatments are important for improving soil structures, which are beneficial for plant growth and physical soil properties (Pöhlitz et al., 2018). TL treatment affects corn grain nutrient composition and yield (Houx et al., 2016). In the present work, the two tillage styles showed different effects on the nutrient uptake in melon plants under facility conditions. Our data showed that in the UT treatment, additional N was absorbed in the leaves and fruit (Figures 1A and 1B), and the $\mathrm{N}$ content was kept constant in the melon stem under the TL treatment. Previous findings have discovered 


\section{CCA}

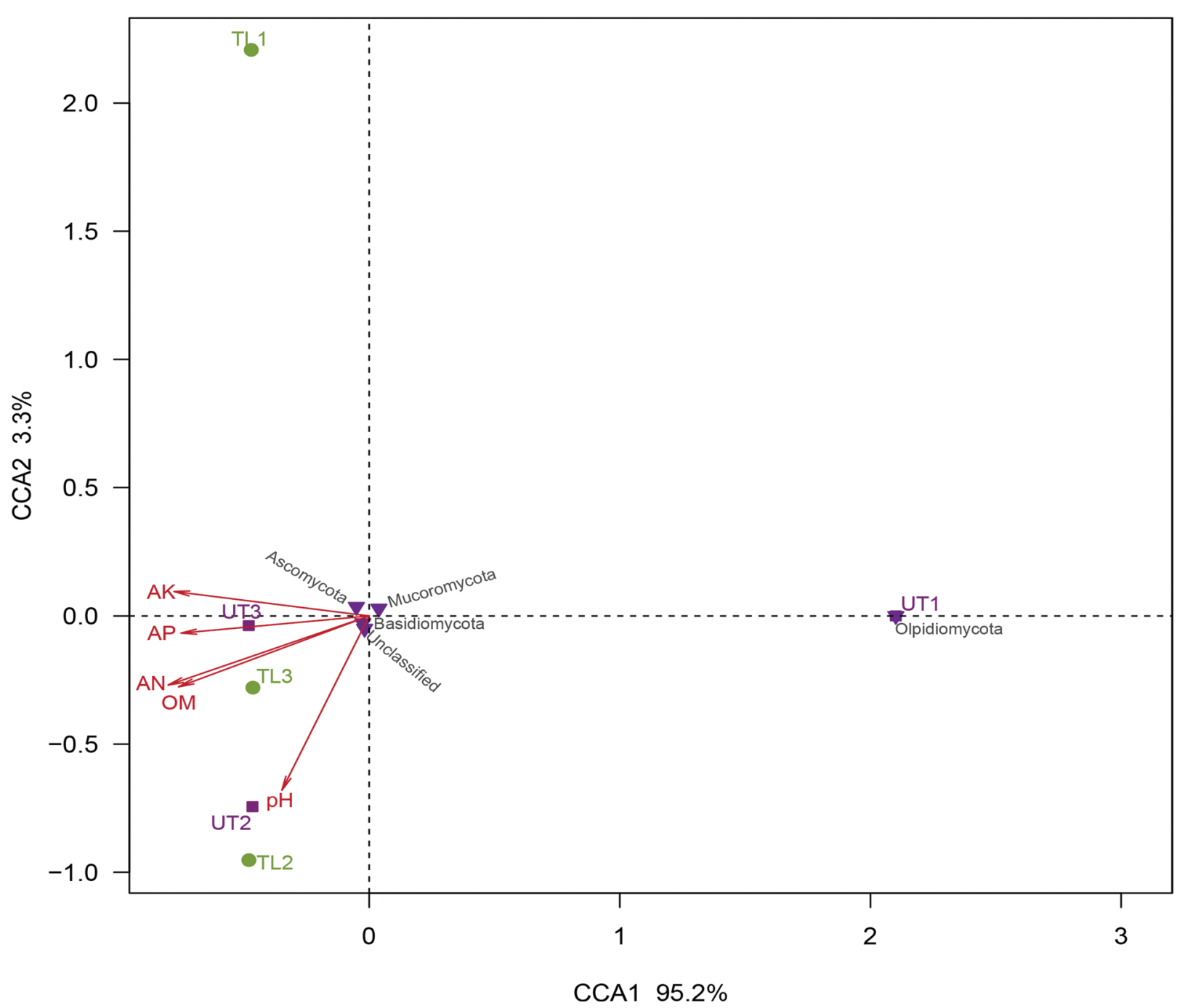

Figure 8. Biplot of species - environmental variables according to the CCA of fungal taxa.

that the autotrophic nitrification rate in the topsoil layer of UT is significantly higher than that of conventional TL (Liu et al., 2017), which provides a reasonable explanation on the absorption of additional $\mathrm{N}$ by the melon plant. TL and $\mathrm{P}$ fertilization showed no significant effects on root $\mathrm{P}$ contents ( $\mathrm{Li}$ et al., 2017). By contrast, the $\mathrm{P}$ contents in leaves and fruits in the UT treatment in our study were higher than the values in TL treatment especially the $\mathrm{P}$ content in fruits $\left({ }^{*} p<0.05\right)$. Although the effect of TL on the dynamics of the P element is not significant (Bünemann et al., 2006), our study showed that different tillage practices can improve the P uptake in the melon plant. Compared with the TL treatment, additional $\mathrm{N}$ and $\mathrm{P}$ were detected in melon plant leaves and fruits under the UT treatment. However, the N and the $\mathrm{P}$ contents were constant in the melon stems under the two treatments (Figure 1C), thereby suggesting that nutrients were absorbed differently in the parts of the melon plant under the two treatments.

Here, additional $\mathrm{K}$ in the fruits under UT treatment was found, whereas high $\mathrm{K}$ content was observed in melon stem under TL treatment. $\mathrm{K}$ can affect fruit quality (Lester et al., 2010). Following previous studies, our data showed that the $\mathrm{K}$ accumulation in melon plants had different amounts under the two treatments. However, in a previous study, TL has produced noeffect on seed K concentrations (Farmaha et al., 2011). Soil management and rotations can affect the $\mathrm{P}$ and $\mathrm{K}$ in soil and increase fertiliser use efficiency (Rosolem and Calonego, 2013). In the present study, under UT treatment, the proper addition of nutrients can increase the N, P, and K contents in leaves and fruits. The total amount of the three elements in the UT treatment $\left(20.41 \mathrm{~g} \cdot\right.$ plant $\left.^{-1}\right)$ was significantly higher than that in the TL treatment $\left(13.14 \mathrm{~g} \cdot\right.$ plant $\left.^{-1}\right)$, thereby suggesting that nutrient uptake can also be improved by adding fertiliser in later management without TL. Melon yield demonstrated that the UT treatment produced more fruits than the TL treatment, thereby indicating that UT treatment can increase melon yields. Similar results have been reported that UT can ensure equivalent or even higher yields than conventional TL (Ruisi et al., 2016). 
Table 3. Soil microbial correlation with melon plant and nutrients

\begin{tabular}{|c|c|c|c|c|c|c|}
\hline $\begin{array}{l}\text { Microbial } \\
\text { groups }\end{array}$ & Nutrients & Soil microbial genus & Correlation & $p$-value & Significant level & Plant part \\
\hline \multirow[t]{8}{*}{ Bacteria } & $\mathrm{TN}, \mathrm{TP}$ and $\mathrm{TK}$ & Pirellula & 0.771 & 0.038 & $*$ & Leaf and Fruit \\
\hline & $\mathrm{TN}$ & Dongia & -0.869 & 0.010 & * & Stem \\
\hline & $\mathrm{TN}$ & Gemmatimonas, Hamadaea & -0.927 & 0.002 & $* *$ & Stem \\
\hline & $\mathrm{TP}$ & Dongia & -0.811 & 0.024 & $*$ & Stem \\
\hline & $\mathrm{TP}$ & Nocardioides, Gemmatimonas & -0.753 & 0.044 & * & Stem \\
\hline & $\mathrm{TP}$ & Planctomycetes & 0.927 & 0.002 & $* *$ & Stem \\
\hline & $\mathrm{TP}$ & Armatimonadetes & -0.898 & 0.005 & $* *$ & Stem \\
\hline & $\mathrm{TP}$ & Patescibacteria & -0.898 & 0.005 & $* *$ & Stem \\
\hline \multirow[t]{11}{*}{ Fungi } & $\mathrm{TN}, \mathrm{TP}$ and TK & Chaetomium & -0.771 & 0.038 & $*$ & Leaf and Fruit \\
\hline & $\mathrm{TN}, \mathrm{TP}$ and $\mathrm{TK}$ & Dendrostilbella & 0.771 & 0.038 & $*$ & Leaf and Fruit \\
\hline & $\mathrm{TN}$ & AcrophialophoraCephaliophora & 0.782 & 0.034 & * & Stem \\
\hline & $\mathrm{TN}$ & Polyschema & -0.898 & 0.005 & $* *$ & Stem \\
\hline & $\mathrm{TN}$ & Cercospora & -0.788 & 0.032 & $*$ & Stem \\
\hline & $\mathrm{TN}$ & Scedosporium & 0.779 & 0.035 & * & Stem \\
\hline & $\mathrm{TN}$ & Verticillium & -0.927 & 0.002 & $* *$ & Stem \\
\hline & $\mathrm{TP}$ & Fusarium & -0.753 & 0.044 & * & Stem \\
\hline & $\mathrm{TP}$ & Cercospora & -0.857 & 0.013 & $*$ & Stem \\
\hline & TK & Dendrostilbella & -0.771 & 0.038 & $*$ & Stem \\
\hline & TK & Ascobolus & -0.885 & 0.007 & $* *$ & Stem \\
\hline
\end{tabular}

$\mathrm{TN}$, total nitrogen; TP, total phosphorus; TK, total potassium.

Hence, the results of the present study indicated that the UT treatment exhibited the same positive effect on the yield of the melon crop compared with TL treatment.

\section{Analysis of microbial community diversities}

Bacterial and fungal diversities changed differently under UT and TL operations. The OTUs in bacteria were higher than those in fungi, and the functional communities in the UT treatment were higher than those in the TL treatment. Results revealed that the predominant bacterial phyla were Proteobacteria, Acidobacteria, Actinobacteria, Gemmatimonadetes and Chloroflexi (Figure 2A). In our previous study, these bacterial phyla are the main groups in greenhouse soils (Zhang et al., 2019). These phyla have also been detected in plateau freshwater lakes or loess plateau (Zeng et al., 2016; Zhang et al., 2015). In the present study, bacterial communities were dominated by the bacterial groups mentioned above in facility soils.

In terms of fungi, the predominant fungal phylum was Ascomycota (Figure 2B). Various studies have demonstrated that Ascomycota is common in soils (Gorfer et al., 2011; Klaubauf et al., 2010). The results of the present study demonstrated that TL treatment resulted in changes in microbial communities, but these changes were not significant. The heatmap analysis exhibited that TL treatment showed less effect on the distribution or shift in bacterial groups than UT treatment (Figure 3). However, only the effect on the fungal groups was detected in initial samples (Figure 4; UT1 and TL1), thereby suggesting that the TL operation can change the fungal distribution before planting. The long-term application of UT caused a significant increase in bacterial diversities compared with that of TL (Dong et al., 2017). UT with organic input management can enhance soil microbial diversity (Wang et al., 2017b). However, in the present study, the microbial structures under the two treatments were similar, thereby suggesting that the UT treatment had the same effect on the bacterial groups as the TL treatment.

\section{CCA and heatmap analyses of soil factors in microbial communities}

A significant negative correlation was observed between the $\mathrm{pH}$ value and Patescibacteria and Armatimonadetes groups. Gemmatimonadetes, Bacteroidetes and Elusimicrobia were negatively correlated with $\mathrm{OM}$ and available N (AN; Figure 6A). These bacterial phyla are considerably influenced by soil properties (Kim et al., 2014; Wolińska et al., 2017). In the fungal community, Verticillium was negatively correlated with $\mathrm{pH}, \mathrm{OM}$ and AN. Ascobolus was negatively correlated with OM, AN, AP and AK. Acrophialophora was positively correlated with $\mathrm{pH}$ (Figure 6B). pH-controlled bacterial distribution was followed by $\mathrm{OM}$ and $\mathrm{AN}$ contents (Figure 7). The soil chemical properties especially soil $\mathrm{pH}$ can remarkably shape microbial communities and control the distribution of microbial structures 
(Shi et al., 2019; Tian et al., 2017). In the present study, $\mathrm{AN}$ and $\mathrm{OM}$ were the main factors affecting the fungal community in the UT and the TL treatments (Figure 8). Soil fungal communities are linked in the long-term fertilised grassland (Cassman et al., 2016). Endophytic fungal communities are also associated with plants in organic and conventional farming systems, including their environmental growth conditions (Xia et al., 2019). Long-term UT increases soil organic carbon content, which influences fungal group distribution (Desanctis et al., 2012).

\section{Correlation of melon plant nutrients with soil microbial communities}

Microbial communities are important for soil quality, and plant species and soil type shape the structure and function of the microbial communities in the plant rhizosphere (Berg and Smalla, 2009; Yao et al., 2003). The correlation of the $\mathrm{N}, \mathrm{P}$, and $\mathrm{K}$ contents that were absorbed by melon plant leaves, stems and fruits with the soil microbial communities was further analysed. However, although the nutrients in different melon parts were correlated to microbial groups, these bacterial or fungal phyla did not decide the nutrient uptake in melon plants. By contrast, the nutrient uptake in melon leaves, stems and fruits may collect those microbial groups. The efficient use of plant nutrient can be enhanced by beneficial bacteria or fungi (Adesemoye et al., 2008). Rhizosphere interactions between microorganisms and plants can also stimulate the $\mathrm{P}$ acquisition in plant roots (Marschner et al., 2011). Here, TN, TP, and TK were significantly positively correlated with Pirellula $(p<0.05)$ in melon leaves and fruits (Table 3). However, TN and TP were negatively correlated with bacterial genera and phyla, such as Gemmatimonas and Nocardioides, in the melon stem. Additional bacterial genera were positively correlated with TP, whereas Patescibacteria and Armatimonadetes were negatively correlated with TP in melon stem (Table 3). Our results suggested that these bacterial genera may promote nutrient uptake. However, precise mechanisms by which these microbial groups can improve the growth of the melon plant should be further investigated. Concerning fungal genera, TN, TP and TK contents in melon leaves and fruits were negatively correlated with Chaetomium and positively correlated with Dendrostilbella. Additional fungal communities were negatively correlated with TN, TP, and TK (Table 3). Previous findings have discovered that chemical fertilisation significantly decreases the diversity of the arbuscular mycorrhizal fungal community structures and is negatively correlated with increased soil nutrients (Liu et al., 2020). As noted above, the data in the present study proved that these bacterial and fungal genera may be correlated with the nutrient uptake in the melon plant. In previous studies, bacteria and fungi have potential abilities to improve plant growth by increasing the uptake of nutrients such as N and P (Rashid et al.,
2016; Xia et al., 2019). The results of the present study indicated that UT can also have significant positive effects on the microbial diversity in soils planted with melon crop under facility conditions.

\section{CONCLUSIONS}

1. The UT and the TL treatments had minimal influence on soil chemical properties and microbial community diversity. The melon yield under the UT treatment was higher than that under the TL treatment.

2. The microbial communities may be correlated with nutrient uptake in melon leaves, stems and fruits. The further investigation focused on the mechanisms underlying the beneficial stimulations of these microbial groups and improvement of the utilisation of these microbial groups are useful in sustainable greenhouse production.

3. This study provided additional insights into the response of soil fertility and microbial structures to UT and TL treatments under greenhouse soils, which may help manage soil quality for the protected field production of melon.

\section{ACKNOWLEDGEMENTS}

We thank Yu Cao and Jing Chen, undergraduate students from the School of Horticulture at Anhui Agricultural University, for their assistance in the experiment.

\section{FUNDING}

This work was supported by the Anhui Key Research and Development Project (Grant No. 201904a06020004), and the National Key Research and Development Programme of China (Grant No. 2018YFD0201309), and the National Natural Science Foundation of China (Grant No. 31701968), and the Second Level Youth Development Fund from Anhui Academy of Agricultural Sciences.

\section{AUTHOR CONTRIBUTIONS}

Z.J. and W.P.C. planned and designed the research. Z.J., W.P.C., W.J.J. and G.T.T. performed the experiments. Z.J. and W.P.C. analysed the data. Z.J. wrote the manuscript. All authors have read and approved the final version.

\section{CONFLICT OF INTEREST}

The authors declare no conflict of interest.

\section{REFERENCES}

Adesemoye, A., Torbert, H., And Kloepper, J. (2008). Enhanced plant nutrient use efficiency with PGPR and $\mathrm{AMF}$ in an integrated nutrient management system. Canadian Journal of Microbiology, 54, 876-886. 
Berg, G., and Smalla, K. (2009). Plant species and soil type cooperatively shape the structure and function of microbial communities in the rhizosphere. FEMS Microbiology Ecology, 68(1), 1-13.

Bremner, J. M. (1960). Determination of nitrogen in soil by the Kjeldahl method. Journal of Agricultural Sciences, 55, 11-33.

Bünemann, E., Heenan, D., Marschner, P., And McneILl, A. (2006). Long-term effects of crop rotation, stubble management and tillage on soil phosphorus dynamics. Soil Research, 44, 611-618.

CAO, P., Li, C., Xiang, W., Wang, X., And ZhaO, J. (2019). First report of Fusarium incarnatum-equiseti species complex causing fruit rot on muskmelon (Cucumis melo) in China. Plant Disease. 103, 1768.

Cassman, N. A., Leite, M. F., Pan, Y., Dehollander, M., Van Veen, J. A., And Kuramae, E. E. (2016). Plant and soil fungal but not soil bacterial communities are linked in long-term fertilized grassland. Scientific Reports, 6, 23680, doi: 10.1038/srep23680.

Chang, J., Wu, X., Liu, A., Wang, Y., Xu, B., Yang, W., Meyerson, L. A., Gu, B., Peng, C., and Ge, Y. (2011). Assessment of net ecosystem services of plastic greenhouse vegetable cultivation in China. Ecological Economics, 70, 740-748.

Chang, J., Wu, X., Wang, Y., Meyerson, L. A., Gu, B., Min, Y., Xue, H., Peng, C., And Ge, Y. (2013). Does growing vegetables in plastic greenhouses enhance regional ecosystem services beyond the food supply? Frontiers in Ecology and the Environment, 11, 43-49.

Desanctis, G., Roggero, P. P., Seddaiu, G., Orsini, R., Porter, C. H., And Jones, J. W. (2012). Long-term no-tillage increased soil organic carbon content of rain-fed cereal systems in a Mediterranean area. European Journal of Agronomy, 40, 18-27.

Dhaene, K., Vermang, J., Cornelis, W.M., Leroy, B. L. M., Schiettecatte, W., Deneve, S., Gabriels, D., and Hofman, G. (2008). Reduced tillage effects on physical properties of silt loam soils growing root crops. Soil Tillage Research, 99, 279-290.

Dong, W., Liu, E., Yan, C., Tian, J., Zhang, H., AND ZHANG, Y. (2017). Impact of no-tillage vs. conventional tillage on the soil bacterial community structure in a winter wheat cropping succession in northern China. European Journal of Soil Biology, $80,35-42$.

Farmaha, B. S., Fernández, F. G., and Nafziger, E. D. (2011). No-till and strip-till soybean production with surface and subsurface phosphorus and potassium fertilization. Agronomy Journal, 103, 1862-1869.

Firouzi, S., Nikkhah, A., And Rosentrater, K. A. (2017). An integrated analysis of non-renewable energy use, GHG emissions, carbon efficiency of groundnut sole cropping and groundnut-bean intercropping agroecosystems. Environmental Progress \& Sustainable Energy, 36, 1832-1839.

Gorfer, M., Blumhoff, M., Klaubauf, S., Urban, A., Inselsbacher,E.,Bandian,D.,Mitter,B.,Sessitsch,A.,
WaneK, W., And Strauss, J. (2011). Community profiling and gene expression of fungal assimilatory nitrate reductases in agricultural soil. ISME Journal, $5,1771-1783$.

Guo, J. H., Liu, X. J., Zhang, Y., Shen, J. L., Han, W. X., Zhang, W. F., Christie, P., Goulding, K. W. T., Vitousek, P. M., And Zhang, F. S. (2010). Significant acidification in major Chinese croplands. Science, 327, 1008-1010.

Haramoto, E. R., and Brainard, D. C. (2012). Strip tillage and oat cover crops increase soil moisture and influence $\mathrm{N}$ mineralization patterns in cabbage. HortScience, 47, 1596-1602.

Houx, J. H., Wiebold, W. J., And Fritschi, F. B. (2016). Long term tillage treatment effects on corn grain nutrient composition and yield. Field Crops Research, 191, 33-40.

Hu, W., Zhang, Y., Huang, B., and Teng, Y. (2017). Soil environmental quality in greenhouse vegetable production systems in eastern China: Current status and management strategies. Chemosphere, 170, 183-195.

Kandlikar, G. S., Johnson, C. A., Yan, X., Kraft, N. J., AND Levine, J. M. (2019). Winning and losing with microbes: How microbially mediated fitness differences influence plant diversity. Ecology Letters, 22, 1178-1191.

Karlen, D. L., Veum, K. S., Sudduth, K. A., Obrycki, J. F., And Nunes, M. R. (2019). Soil health assessment: Past accomplishments, current activities, and future opportunities. Soil Tillage Research, 195, 104365.

Kim, H. M., Jung, J. Y., Yergeau, E., Hwang, C. Y., Hinzman, L., Nam, S., Hong, S. G., Kim, O. S., Chun, J., AND LEE, Y. K. (2014). Bacterial community structure and soil properties of a subarctic tundra soil in Council, Alaska. FEMS Microbiology Ecology, 89, 465-475.

Klaubauf, S., Inselsbacher, E., ZechmeisterBoltenstern, S., Wanek, W., Gottsberger, R., Strauss, J., AND Gorfer, M. (2010). Molecular diversity of fungal communities in agricultural soils from Lower Austria. Fungal Diversity, 44, 65-75.

Kumar, A., NG, D. H., Wu, Y., and CaO, B. (2019). Microbial community composition and putative biogeochemical functions in the sediment and water of tropical granite quarry lakes. Microbial Ecology, 77, 1-11.

Lester, G. E., Jifon, J. L., And Makus, D. J. (2010). Impact of potassium nutrition on postharvest fruit quality: Melon (Cucumis melo L) case study. Plant and Soil, 335, 117-131.

Li, F. M., Song, Q. H., Jjemba, P. K., And Shi, Y. C. (2004). Dynamics of soil microbial biomass $C$ and soil fertility in cropland mulched with plastic film in a semiarid agro-ecosystem. Soil Biology and Biochemistry, 36, 1893-1902.

Li, H., Mollier, A., Ziadi, N., Shi, Y., Parent, L. É., And Morel, C. (2017). The long-term effects of tillage practice and phosphorus fertilization on the 
distribution and morphology of corn root. Plant and Soil, 412, 97-114.

Li, S., Ni, X., XIA, Q., Li, Y., Dong, X., Hou, J., Li, Z., Cheng, S., CaO, D., and Zhang, Z. (2019). Rapid characterization of the genetic loci controlling commodity traits of Chinese hami melon (Cucumis melo var. Saccharinensis Naud.) through multiplexed shotgun genotyping. Agronomy, 9(8), 430, doi: 10.3390/agronomy9080430.

Liu, J., Zhang, J., Li, D., Xu, C., And Xiang, X. (2020). Differential responses of arbuscular mycorrhizal fungal communities to mineral and organic fertilization. MicrobiologyOpen, 9, e00920, doi: 10.1002/ mbo3.920.

Liu, S., Zhang, X., Zhao, J., Zhang, J., Müller, C., AND CAI, Z. (2017). Effects of long-term no-tillage treatment on gross soil $\mathrm{N}$ transformations in black soil in Northeast China. Geoderma, 301, 42-46.

Marschner, P., Crowley, D., and Rengel, Z. (2011). Rhizosphere interactions between microorganisms and plants govern iron and phosphorus acquisition along the root axis-model and research methods. Soil Biology and Biochemistry, 43, 883-894.

Muller, A., Ferré, M., Engel, S., Gattinger, A., Holzkämper, A., Huber, R., Müller, M., And Six, J. (2017). Can soil-less crop production be a sustainable option for soil conservation and future agriculture? Land Use Policy, 69, 102-105.

O'rourke, M. E., And Petersen, J. (2016). Reduced tillage impacts on pumpkin yield, weed pressure, soil moisture, and soil erosion. HortScience, 51(12), 1524-1528.

Pöhlitz, J., Rücknagel, J., Koblenz, B., Schlüter, S., Vogel, H. J., And Christen, O. (2018). Computed tomography and soil physical measurements of compaction behaviour under strip tillage, mulch tillage and no-tillage. Soil Tillage Research, 175, 205-216.

Rashid, M. I., Mujawar, L. H., Shahzad, T., Almeelbi, T., Ismail, I. M. I., AND Oves, M. (2016). Bacteria and fungi can contribute to nutrients bioavailability and aggregate formation in degraded soils. Microbiological Research, 183, 26-41.

Rosolem, C. A., And Calonego, J. C. (2013). Phosphorus and potassium budget in the soil-plant system in crop rotations under no-till. Soil Tillage Research, 126, 127-133.

Ruisi, P., Saia, S., Badagliacca, G., Аmato, G., Frenda, A. S., Giambalvo, D., and Dimiceli, G. (2016). Long-term effects of no-tillage treatment on soil $\mathrm{N}$ availability, $\mathrm{N}$ uptake, and $15 \mathrm{~N}$-fertilizer recovery of durum wheat differ in relation to crop sequence. Field Crops Research, 189, 51-58.

Shen, C., Xiong, J., Zhang, H., Feng, Y., Lin, X., Li, X., Liang, W., And Chu, H. (2013). Soil pH drives the spatial distribution of bacterial communities along elevation on Changbai Mountain. Soil Biology and Biochemistry, 57, 204-211.
Shi, S., Tian, L., Nasir, F., Bahadur, A., Batool, A., Luo, S., Yang, F., Wang, Z., and Tian, C. (2019). Response of microbial communities and enzyme activities to amendments in saline-alkaline soils. Applied Soil Ecology, 135, 16-24.

Sıösten, A., AND BlomQvist, S. (1997). Influence of phosphate concentration and reaction temperature when using the molybdenum blue method for determination of phosphate in water. Water Research, 31, 1818-1823.

Sun, R., Zhang, X. X., Guo, X., Wang, D., And Chu, H. (2015). Bacterial diversity in soils subjected to long-term chemical fertilization can be more stably maintained with the addition of livestock manure than wheat straw. Soil Biology and Biochemistry, 88, 9-18.

Tian, Q., Taniguchi, T., Shi, W.Y., Li, G., Yamanaka, N., AND Du, S. (2017). Land-use types and soil chemical properties influence soil microbial communities in the semiarid Loess Plateau region in China. Scientific Reports, 7, 45289, doi: 10.1038/srep45289.

Tillman, J., Nair, A., Gleason, M., and Batzer, J. (2015). Evaluating strip tillage and rowcover use in organic and conventional muskmelon production. HortTechnology, 25(4), 487-495.

Touceda-González, M., Brader, G., Antonielli, L., Ravindran, V. B., Waldner, G., Friesl-Hanl, W., Corretto, E., Campisano, A., Pancher, M., And Sessitsch, A. (2015). Combined amendment of immobilizers and the plant growth-promoting strain Burkholderia phytofirmans PsJN favours plant growth and reduces heavy metal uptake. Soil Biology and Biochemistry, 91, 140-150.

Wang, T., Wu, G., Chen, J., Cui, P., Chen, Z., Yan, Y., Zhang, Y., Li, M., Niu, D., Li, B., And Chen, H. (2017a). Integration of solar technology to modern greenhouse in China: Current status, challenges and prospect. Renew. Renewable and Sustainable Energy Reviews, 70, 1178-1188.

Wang, Y., Li, C., Tu, C., Hoyt, G. D., Deforest, J. L., And Hu, S. (2017b). Long-term no-tillage and organic input management enhanced the diversity and stability of soil microbial community. Science of the Total Environment, 609, 341-347.

WANG, Z. G., Jin, X., BAO, X. G., Li, X. F., ZhaO, J. H., Sun, J. H., Christie, P., AND Li, L. (2014). Intercropping enhances productivity and maintains the most soil fertility properties relative to sole cropping. PLoS ONE, 9, e113984, doi: 10.1371/journal.pone.0113984.

WolińsKa, A., Kuźniar, A., Zielenkiewicz, U., IzaK, D., SZAFrANEK-NAKONIECZnA, A., BANACH, A., AND BŁAszczyK, M. (2017). Bacteroidetes as a sensitive biological indicator of agricultural soil usage revealed by a culture-independent approach. Applied Soil Ecology, 119, 128-137.

Xia, Y., Sahib, M. R., Amna, A., Opiyo, S. O., ZhaO, Z., AND GAO, Y. G. (2019). Culturable endophytic fungal communities associated with plants in 
organic and conventional farming systems and their effects on plant growth. Scientific Reports, 9, 1669, doi: 10.1038/s41598-018-38230-x.

Xue, M., Guo, Z., Gu, X., Gao, H., Weng, S., Zhou, J., Gu, D., Lu, H., And Zhou, X. (2020). Rare rather than abundant microbial communities drive the effects of long-term greenhouse cultivation on ecosystem functions in subtropical agricultural soils. Science of the Total Environment, 706, 136004.

Yan, Z., Li, W., Yan, T., Chang, S., And Hou, F. (2019). Evaluation of energy balances and greenhouse gas emissions from different agricultural production systems in Minqin Oasis, China. PeerJ, 7, e6890, doi: $10.7717 /$ peerj.6890.

Yao, H., Xu, J., And Huang, C. (2003). Substrate utilization pattern, biomass and activity of microbial communities in a sequence of heavy metal-polluted paddy soils. Geoderma, 115, 139-148.

Yeboah, S., Reanzhi, Z., Liqun, C., and Jun, W. (2018). Different carbon sources enhance system productivity and reduce greenhouse gas intensity. Plant, Soil and Environment. 64, 463-469.

Zeng, Q., Dong, Y., AND An, S. (2016). Bacterial community responses to soils along a latitudinal and vegetation gradient on the Loess Plateau, China. PLoS ONE, 11, e0152894, doi: 10.1371/journal. pone.0152894.

Zhang, C., Li, S., Yang, L., Huang, P., Li, W., Wang, S., ZhaO, G., Zhang, M., Pang, X., Yan, Z., Liu, Y., AND ZhaO, L. (2013). Structural modulation of gut microbiota in life-long calorie-restricted mice. Nature Communications, 4, 2163, doi: 10.1038/ ncomms3163.

Zhang, C., Lin, T., Li, J., Ma, G., Wang, Y., Zhu, P., AND XU, L. (2016a). First report of the melon stem rot disease in protected cultivation caused by Pseudomonas fluorescens. Journal of Plant Diseases and Protection, 123, 247-255.

Zhang, H., Wang, H., Yi, H., Zhai, W., Wang, G., And FU, Q. (2016b). Transcriptome profiling of Cucumis melo fruit development and ripening. Horticulture Research, 3, 1-10.

Zhang, J., Wang, P. C., Tian, H. M., XiaO, Q. Q., AND JiAnG, H. K. (2019). Pyrosequencing-based assessment of soil microbial community structure and analysis of soil properties with vegetable planted at different years under greenhouse conditions. Soil Tillage Research, 187, 1--10.

Zhang, J., Yang, Y., Zhao, L., Li, Y., Xie, S., and Liu, Y. (2015). Distribution of sediment bacterial and archaeal communities in plateau freshwater lakes. Applied Microbiology and Biotechnology, 99, 3291-3302.

Zhou, H., Wang, G., Wu, M., Xu, W., Zhang, X., And LiU, L. (2018). Phenol removal performance and microbial community shift during $\mathrm{pH}$ shock in a moving bed biofilm reactor (MBBR). Journal of Hazardous Materials, 351, 71-79.

Received June 23, 2020; accepted September 04, 2020. 